\title{
Consequences of walking or transport by truck on milk yield and quality, as well as blood metabolites, in Holstein, Montbéliarde, and Valdostana dairy cows
}

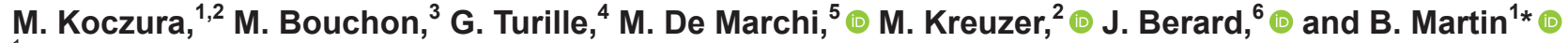 \\ ${ }^{1}$ Université Clermont Auvergne, INRAE, VetAgro Sup, UMR1213 Herbivores, 63122 Saint-Genès-Champanelle, France \\ ${ }^{2}$ ETH Zurich, Institute of Agricultural Sciences, Universitaetstrasse 2, 8092 Zurich, Switzerland \\ ${ }^{3}$ Université Clermont Auvergne, INRAE, UE Herbipôle, 15190 Marcenat, France \\ ${ }^{4}$ Institut Agricole Régional-Regione La Rochere 1/A, 11100 Aosta, Italy \\ ${ }^{5}$ Department of Agronomy, Food, Natural Resources, Animals and Environment, University of Padova, Viale dell'Università 16, 35020 Legnaro, \\ Padua, Italy \\ ${ }^{6}$ ETH Zurich, AgroVet-Strickhof, Eschikon 27, 8315 Lindau, Switzerland
}

\section{ABSTRACT}

In the mountains, the traditional practice of transhumance is common in dairy production systems to make use of the high-altitude summer pastures. Although the effects of highland grazing have been intensively studied with respect to cow performance and milk and cheese quality, the actual moving of the animals to the highlands and the consequences of this stressor for performance and milk quality in the days immediately following transhumance has not been investigated in detail. The aim of the present study was to compare the effects of a 6 -km walk (lasting $1.5 \mathrm{~h}$ ) to those of a truck transport of $10.5 \mathrm{~km}$ (lasting $1 \mathrm{~h}$ ), simulating cow movement in transhumance systems, as well as a control treatment in which cows were not moved. The experiment included 12 late-lactating Valdostana Red Pied, 12 Montbéliarde, and 12 Holstein cows (i.e., breeds contrasting in genetic merit for milk production). Each cow was subjected to each treatment in a 3 -wk Latin square design. Milk yield was measured, and milk and blood samples were taken around the transhumance simulation events. Cows of the 3 breeds responded similarly to both movement treatments. Walking decreased milk yield by $1 \mathrm{~kg} /$ milking, but truck transport did not affect milk yield. Both treatments led to an increase in plasma nonesterified fatty acids and milk somatic cell count compared with controls, and truck transport increased milk fat content. Milk coagulation properties were better for Valdostana Red Pied and Montbéliarde cows than for Holstein cows but were not affected by walking or truck transport. Further studies aiming to

Received August 19, 2019.

Accepted December 18, 2019.

*Corresponding author: bruno.martin@inra.fr compare the 3 breeds should include a wider range of response variables over a longer term, including reproduction performance and repeated transhumance.

Key words: transhumance, dairy cow, blood metabolites, milk coagulation

\section{INTRODUCTION}

Transhumance is a traditional practice used to make use of high-altitude summer pastures in mountain dairy systems around the world. Several studies have highlighted the effects of highland grazing on milk and cheese quality. Milk produced on mountain pastures has a higher fat content and is particularly rich in beneficial functional fatty acids. However, it also has a lower protein content and sometimes less favorable cheesemaking properties (Hauswirth et al., 2004; Leiber et al., 2005; Koczura et al., 2019a). Studies involving the effect of transhumance on milk and cheese quality on a seasonal scale have shown that milk yield decreases on highland pastures and SCC increases (Zendri et al., 2016; Niero et al., 2018). Mountain grazing conditions are therefore strongly related to changes in milk properties in the medium term (i.e., within a few weeks after arriving on the pasture). In the short term, it has been demonstrated on farm that milk composition is altered on the day directly after transhumance movement (Koczura et al., 2019b), with high fat content and elevated SCC. However, transhumance involves various factors that may affect milk in the short term, including stress caused by arriving at an unknown, often steep, grazing area with less dense forage growth; different grass quality; low oxygen partial pressure; changed milking equipment; and stress resulting from the actual movement of cows to these pastures. During transhumance, cows traditionally walk from the lowlands to the highland pastures or are transported by truck when 
topography allows it. Long-distance walks $(>12 \mathrm{~km})$ have been found to increase milk fat content and SCC (D'Hour et al., 1994) and decrease cows' feed intake, followed by a decline in milk yield (Coulon and Pradel, 1997). However, these results were obtained under experimental stall-feeding conditions and with much longer walks than those typically needed to move cows between alpine grazing sites, as described by Koczura et al. (2019b). As well, Magrin et al. (2016) suggested that walking dairy cows with contrasting milk production levels showed decreased milk yield in different proportions. The effects of transporting animals by truck have been investigated, especially with respect to hematological and metabolic changes caused by transport stress (Minka and Ayo, 2010). However, these studies mostly dealt with growing animals, and were rarely carried out under mountainous conditions. A report by Ishizaki and Kariya (2010) found elevated plasma cortisol and total leukocyte levels in calves moved by truck in a mountainous area, compared with calves transported in a flat area. Similar findings were demonstrated by Kreuzer et al. (1998), who reported that dairy cows produced increased levels of stress indicators such as cortisol, lactate, and nonesterified fatty acids (NEFA) during several hours of transport by truck. Recently, Hong et al. (2019) described a 4-h transport of dairy cows by truck, which led to decreased milk yield and increased milk SCC. However, to date, the effects of truck transport on milk quality and rennet coagulation properties have been poorly investigated. The latter is particularly important for upland transhumance systems, where cheesemakers claim that cheese produced from milk around transhumance events is impaired. Moreover, a direct comparison of the effects of walking and truck transport in cows from breeds with contrasting milk production potential is lacking.

The aim of the present study was to evaluate the effects of moving dairy cows (3 breeds contrasting in genetic merit for milk production) between mountainous sites on cow performance, blood metabolites, and milk quality and coagulation traits. We purposely excluded all confounding effects of transhumance (e.g., change in altitude and pasture) and focused exclusively on the comparative effect of moving the dairy cows by walking or truck transport. We hypothesized that (1) moving cows between sites several kilometers apart would affect the composition of their milk and its coagulation properties; (2) with short times of transport such as those found in mountain transhumance, walking the cows would have more severe effects than truck transport; and (3) the effects of moving would be more prominent in cows from breeds with greater genetic merit for milk production.

\section{MATERIALS AND METHODS}

\section{Animals and Experimental Design}

The experiment took place at the INRA experimental farm "Marcenat" (Herbipôle, 45 $15^{\circ} \mathrm{N}, 2^{\circ} 55^{\prime} \mathrm{E}$; between 1,135 and 1,215 $\mathrm{m}$ above sea level) in 2017 . All animal-related procedures were carried out in accordance with the guidelines for animal research of the French Ministry of Agriculture and all other applicable national and European guidelines and regulations for experimentation with animals (www2.vet-lyon.fr/ens/ expa/acc_regl.html).

At the beginning of the experiment, 36 late-lactating multiparous dairy cows with different experience backgrounds and genetic merit for milk yield were monitored: 12 Valdostana Red Pied cows (milk yield potential 4,000 kg/lactation, $192 \pm 33$ DIM), 12 Montbéliarde cows (milk yield potential 5,900 kg/lactation, $218 \pm$ 23 DIM) and 12 Holstein cows (milk yield potential $6,700 \mathrm{~kg} /$ lactation, $238 \pm 33 \mathrm{DIM})$. The Holstein and Montbéliarde cows originated from the experimental farm of Marcenat and had already experienced walking and truck transport. The Valdostana Red Pied cows had been transferred to Marcenat by truck from the Institut Agricole Régional (Aosta, Italy) 2 mo before the experiment started, and recovered their initial milk yield from before the transfer within a few days after their arrival (data not shown). In Italy, the Valdostana Red Pied cows were moved by truck and walked to high alpine pastures every year in summer. Seven weeks after the arrival of the Valdostana Red Pied cows, 3 groups balanced by breed (4 cows per breed) and milk yield were created in a complete randomized design. Each group grazed separately (0.3 ha/cow) for $24 \mathrm{~h} / \mathrm{d}$ on flat grass-dominated pastures; cows did not receive concentrate. When the experiment started, milk yields $[\mathrm{kg} / \mathrm{d}$, mean \pm standard deviation $(\mathbf{S D})]$ were $9.9 \pm$ $2.0,14.3 \pm 1.7$, and $13.6 \pm 2.4$ for Valdostana Red Pied, Montbéliarde, and Holstein cows, respectively.

The experiment started on July 1, 2017, and lasted for 3 wk. Following a Latin square design, 3 groups of 4 cows per breed underwent 3 treatments in succession (walking, truck transport, and control) between 1000 and $1200 \mathrm{~h}$ on d 2 of each week, resulting in 12 cows per treatment. Both moving treatments (walking and truck transport) consisted of a loop circuit that departed from the barn where milking took place and ending there as well. The walking treatment consisted of a $6-\mathrm{km}$ walk on a flat path. This treatment was intended to last for $1 \mathrm{~h}$, but actually lasted $1.5 \mathrm{~h}$ on average. Cows were guided by 1 person in front and followed in the back by 2 people encouraging latecomers. During 
the truck transport treatment, cows were transported for $1 \mathrm{~h}$ in a truck that followed a $10.5-\mathrm{km}$ winding mountain road. Cows were guided into the truck at the exit of the milking parlor and kept with a stocking density of $1.6 \mathrm{~m}^{2}$ per animal. To minimize walking effort in cows exposed to the control treatment, cows were kept in an already grazed paddock next to the barn where they were milked. After all treatments ended, cows returned to the barn for the sampling session and then to the pasture they had been grazing before. Cows were milked at 0730 and $1600 \mathrm{~h}$, and milk yield was automatically recorded at each milking (herringbone system; DeLaval, Tumba, Sweden).

\section{Milk Sampling and Analyses of Chemical, Lipolysis, and Coagulation Properties}

On the day before treatment $(\mathrm{d}-1)$, the day of treatment (d 0), and the 2 subsequent days (d 1 and 2), individual milk samples were collected at evening milking. Samples were preserved with 2-bromo-2-nitropropane-1,3-diol (Bronopol; D\&F Inc., Dublin, CA) at $4^{\circ} \mathrm{C}$ until analysis of fat, protein, lactose, and casein contents, as well as lipolysis, was carried out by infrared spectroscopy (LIAL, Aurillac, France; accredited by Cofrac Nr. 1-0196, ISO 9622, 2013). The SCC in $1 \mathrm{~mL}$ of milk was measured by epifluorescence (LIAL, ISO 13366-2, 2006). Additional samples of $50 \mathrm{~mL}$ of evening milk were stored at $-20^{\circ} \mathrm{C}$ and analyzed later for milk coagulation properties (rennet coagulation time, min) and curd firmness $\left(\mathbf{a}_{30} ; \mathrm{mm}\right)$ using a Formagraph (Foss Electronics, Hillerød, Denmark). According to Ikonen et al. (1999) and Cassandro et al. (2008), milk samples that did not coagulate within 30 min were classified as noncoagulating (NC). On d -1 and d 0 , lipoprotein lipase activity in evening milk was measured according to Ferlay et al. (2006).

\section{Blood Metabolites}

Individual blood samples were taken from the tail vein of cows $12 \pm 1 \mathrm{~h}$ before treatment, $0.25 \pm 0.15$ $\mathrm{h}$ and $6 \pm 1 \mathrm{~h}$ afterward (mean $\pm \mathrm{SD}$ ) and stored in EDTA-containing evacuated tubes (Terumo France, Guyancourt, France). Blood sampling was always done first in the control cows, then in the cows transported by truck right (after their arrival), and finally in the walked cows. Because cows arrived later from walking, this was possible at the same time after treatment. Within each treatment group, sampling was performed in a randomized order with respect to breed. Blood samples were immediately centrifuged for $20 \mathrm{~min}$ at $1,200 \times g$ and $4^{\circ} \mathrm{C}$. Blood plasma was then stored at $-20^{\circ} \mathrm{C}$ until analysis of concentrations of the follow- ing metabolites related to physical exercise: NEFA (Arena 20 XT Chemistry System; Thermo Scientific, Waltham, MA), BHB (984325; Thermo Scientific), glucose (981379; Thermo Scientific), and urea (981818; Thermo Scientific).

\section{Statistical Analysis}

Milk composition data in which SCC was $>6,000 \times$ $10^{3}$ cells $/ \mathrm{mL}$ were considered missing values. All SCC data were log-transformed to achieve normal distribution, but in the tables, arithmetic means are presented. In addition, when calculating treatment means for coagulation properties, noncoagulating samples were treated as missing values. Normality of the data and residues were checked using the Shapiro-Wilk test. Data were subjected to ANOVA, applying a repeated mixed model in SAS version 9.4 (SAS Institute Inc., Cary, NC). Breed (Valdostana Red Pied, Montbéliarde, or Holstein), treatment (walking, truck transport, or control), day $(-1,0,1$, or 2$)$ for milk properties or hour $(-12,0.25$, or 6$)$ for blood metabolites (called "time"), and the interactions treatment $x$ time and breed $\times$ treatment $\times$ time were considered as fixed effects. The repeated factor was day within week, and the individual cow was the subject. Week, group, and breed within group were used as random factors. The covariance structure was compound symmetry. Individual cow was considered the statistical unit because social interactions within group were expected to play a minor role in the investigated traits (performance, milk properties, and blood metabolites). In addition, group effect was taken into account in the experimental design itself and as a random factor in the model. Least squares means were compared using Tukey's adjustment. Percentages of coagulating and NC samples were compared using the $\chi^{2}$ test. Compositional data of coagulating and NC milk samples were compared using 2 -sided $t$-tests. For this comparison, we created another data set considering samples with $\mathrm{SCC}>6,000 \times 10^{3}$ cells $/ \mathrm{mL}$. The level of significance was set at $P<0.05$.

\section{RESULTS AND DISCUSSION}

\section{Effect of Moving Treatments on Milk Yield and Blood Metabolites}

Milk yield was similar for the 3 groups on d 0 (Table 1). However, milk yield decreased between $d-1$ and $d$ 0 directly after walking, in contrast to that in the truck transport and control treatments. The lower milk yield on $\mathrm{d}-1$ for truck and control cows may have resulted from persistent adverse effects of walking. Indeed, in contrast to findings from Coulon and Pradel (1997) but 
similar to the observations of Magrin et al. (2016) and Koczura et al. (2019b), the decline in milk yield after walking was not recovered after $2 \mathrm{~d}$. In our Latin square design, cows in the truck transport and control groups were in the walking treatment during 1 of the preceding 2 wk, decreasing their milk yield. When they started the truck transport or control treatment arm of the study, these late-lactating cows had not fully recovered their initial production. Under real farming conditions, seasonal calving is performed in the winter to avoid calving on mountain pastures. In this respect, the cows investigated under experimental conditions by Coulon and Pradel (1997) were in an earlier stage of lactation than the cows investigated by Magrin et al. (2016), Koczura et al. (2019b), and in the present study, where actual conditions of transhumance were simulated. This may explain the persistence of the effect of the walk on milk yield after $2 \mathrm{~d}$ in our experiment.

The decrease in milk yield of $1.4 \mathrm{~kg} / \mathrm{d}$ and $1.0 \mathrm{~kg} /$ milking observed in our study was similar to that ob-

Table 1. Effect of moving treatment on milk yield and evening milk composition, coagulation properties, lipolysis, and lipoprotein lipase (LPL) activity

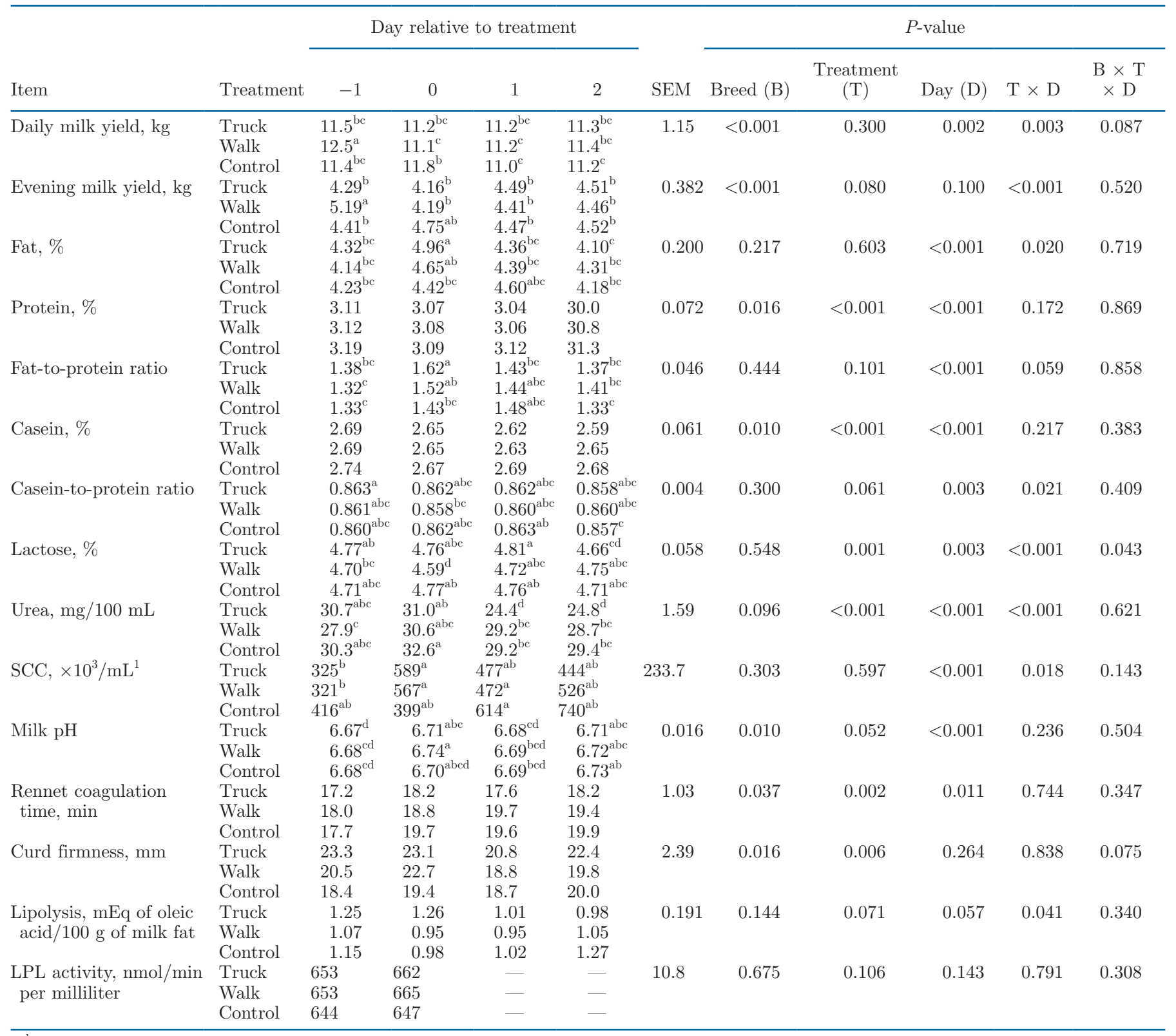

\footnotetext{
${ }^{\mathrm{a}-\mathrm{d}}$ Values within a variable with different superscripts differed at $P<0.05$ by day and by treatment.
}

${ }^{1}$ Arithmetic means are presented; statistical analysis was performed on logarithmic values. 
Table 2. Concentration ( $\mu \mathrm{mol} / \mathrm{L}$ ) of blood metabolites $12 \mathrm{~h}$ before, $0.25 \mathrm{~h}$ after, and $6 \mathrm{~h}$ after moving treatment

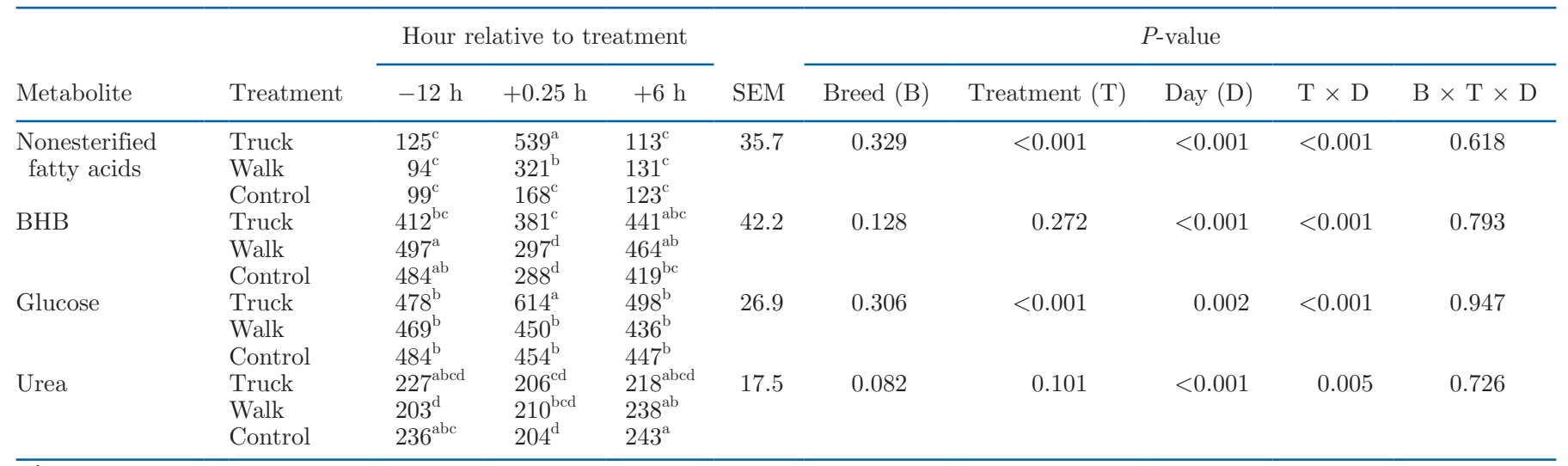

${ }^{\mathrm{a}-\mathrm{d}}$ Values within a variable with different superscripts differed at $P<0.05$ by day and by treatment.

served in a previous study $(-1.2$ and $-1.3 \mathrm{~kg}$ in the 2 subsequent milkings; Coulon and Pradel, 1997), although cows walked for a shorter time in the present study. Investigation of walked transhumance in real on-farm conditions was accompanied by a similar decrease in milk yield $(-1.5 \mathrm{~kg} /$ milking; Koczura et al., 2019b). Our findings suggest that the temporary decrease in milk yield observed by these authors the day after transhumance was mostly because the cows were walking. In contrast, truck transport did not affect milk yield, although a certain impairment could have been expected. Truck transport, associated with vibrations, noise, proximity between animals, and the need for energy to counteract lateral movements on curvy roads, induces high levels of stress (Kreuzer et al., 1998; Minka and Ayo, 2010). It is possible that the duration of transport was not long enough to cause a significant decrease in milk yield.

The decrease in milk yield after walking observed in the present study was most likely related to extra energy expenditure needed to cope with the physical effort. Consistent with this finding, plasma NEFA levels were 3 times higher $0.25 \mathrm{~h}$ after walking (Table 2). A similar increase in plasma NEFA was observed by Magrin et al. (2016) after long walks. At the same time, BHB concentrations decreased, showing that the time of energy deficiency was too short for ketone bodies from fatty acid overload to appear. Although milk yield was not impaired by truck transport, plasma NEFA and glucose levels increased $0.25 \mathrm{~h}$ after transport, to 4 and 1.3 times higher than on $\mathrm{d}-1$, respectively (Table $2)$. This increase was higher in cows that were transported by truck than in cows that walked. Kreuzer et al. (1998) also observed an increase in plasma NEFA and glucose due to transport, to a much higher level. However, the duration of transport in that study was $5 \mathrm{~h}$, whereas cows in the present study spent only $1 \mathrm{~h}$ in the truck. All concentrations of blood metabolites returned to previous level $6 \mathrm{~h}$ after the treatments, except for urea, which was higher by $17 \%$. Walking cows seemed to mobilize body fat reserves to cope with the physical exercise and decreased their milk yield accordingly, whereas cows transported by truck evidently mobilized reserves without decreasing milk production.

\section{Effect of Moving Treatments on Milk Composition}

Milk fat content increased by $0.64 \%$ on d 0 after truck transport, and increased by 0.51 and $0.19 \%$ after walking and control treatments, respectively (Table 1). Because milk protein content was not affected, the fatto-protein ratio increased in both moving treatments on the same day (by 0.24 for truck transport and 0.20 for walking). A clear increase in milk fat content was expected on the day after walking, as observed by Koczura et al. (2019b) the day after transhumance $(+0.41 \%)$. Coulon and Pradel (1997) reported an increase by $0.6 \%$ after a longer walk. Part of this increase was likely due to a concentration effect, resulting from the concomitant decrease in milk yield, and the rest can be explained by body fat mobilization. However, in the present study, milk fat content increased more in cows transported by truck than in cows walking. This was consistent with the increase in plasma NEFA described above.

The SCC of cows increased in both moving treatments on d 0 compared with d $-1\left(+264 \times 10^{3}\right.$ and $+246 \times 10^{3}$ cells $/ \mathrm{mL}$ for truck transport and walking, respectively), in contrast to the control treatment. Coulon and Pradel (1997) observed a large increase in SCC the day after walking, whereas the increase described by Koczura et al. (2019b) was 3 times smaller. The SCC found on d 0 might be linked to the initially high levels occurring the day before walking, which were higher 
Table 3. Proportion and chemical composition of coagulating and noncoagulating milk samples

\begin{tabular}{|c|c|c|c|c|}
\hline \multirow[b]{2}{*}{ Item } & \multicolumn{2}{|c|}{ Milk property } & \multirow[b]{2}{*}{ SEM } & \multirow[b]{2}{*}{$P$-value } \\
\hline & Coagulating & Noncoagulating $^{1}$ & & \\
\hline Proportion of samples, ${ }^{2} \%$ & 80 & 20 & & \\
\hline Treatment & & & & 0.224 \\
\hline Truck & 85 & 15 & - & \\
\hline Walk & 78 & 22 & - & \\
\hline Control & 77 & 23 & - & \\
\hline Breed type $^{2}$ & & & & $<0.001$ \\
\hline Valdostana Red Pied & 94 & 6 & - & \\
\hline Montbéliarde & 88 & 13 & - & \\
\hline Holstein & 58 & 42 & - & \\
\hline \multicolumn{5}{|l|}{ Milk composition $^{3}$} \\
\hline Fat, \% & 4.48 & 4.30 & 0.106 & 0.109 \\
\hline Protein, $\%$ & 3.17 & 3.28 & 0.068 & 0.128 \\
\hline Fat-to-protein ratio & 1.42 & 1.33 & 0.029 & 0.005 \\
\hline Casein, $\%$ & 2.72 & 2.77 & 0.054 & 0.467 \\
\hline Casein-to-protein ratio & 0.861 & 0.845 & 0.002 & $<0.001$ \\
\hline Lactose, $\%$ & 4.77 & 4.37 & 0.044 & $<0.001$ \\
\hline Urea, mg/100 mL & 29.2 & 28.8 & 0.53 & 0.559 \\
\hline $\mathrm{SCC}, \times 10^{3} / \mathrm{mL}^{4}$ & 580 & 1813 & 285.6 & $<0.001$ \\
\hline Milk pH & 6.68 & 6.85 & 0.017 & $<0.001$ \\
\hline
\end{tabular}

in the present study than in Koczura et al. (2019b). The decrease in milk yield might explain part of the increase in SCC in cows that walked, but not in cows that were transported by truck. In fact, the motion of the mammary gland and the inflammation caused by walking or truck transport could trigger a transfer of somatic cells from blood to milk (Coulon et al., 2004). The latter explanation is likely the cause of the increase in SCC after both moving treatments.

Milk $\mathrm{pH}$ also increased the day after both moving treatments (Table 1), by 0.04 and 0.06 for truck transport and walking, respectively, consistent with the increase in SCC. This change did not affect rennet coagulation time or $\mathrm{a}_{30}$. Lipolysis is negatively correlated with milk yield (Chazal and Chilliard, 1986), and tissue mobilization might be linked to higher spontaneous lipolysis in milk (Vanbergue et al., 2018). Therefore, an increase in lipolysis was expected on d 0 for moving treatments. However, neither lipolysis nor lipoprotein lipase activity was affected by walking or truck transport on the day following these treatments. To our knowledge, this factor has not been studied before. In the present study, $20 \%$ of the individual milk samples did not coagulate within $30 \mathrm{~min}$ (Table 3), a slightly higher proportion than that observed by Niero et al. (2018). Compared with coagulating samples, NC samples had lower fat-toprotein and casein-to-protein ratios, an SCC that was twice as high, a lower lactose content $(-0.4 \%)$, and an increased $\mathrm{pH}(+0.17)$. The elevated $\mathrm{pH}$ and SCC con- tent of NC samples were consistent with the inability of the milk to coagulate within $30 \mathrm{~min}$, because high SCC and $\mathrm{pH}$ are usually associated with slow coagulation (Coulon et al., 2004). Similar results were reported by Visentin et al. (2015) in an Irish study, in which lower milk $\mathrm{pH}$ values were associated with more favorable milk coagulation properties.

\section{Lack of Difference in Responses of Breed Types to Moving Treatments}

In contrast to our hypothesis, the 3 breeds did not perform differently the day after the moving treatments, although their global performance throughout the experiment was different. Valdostana Red Pied cows had the lowest milk yield (Table 4), even lower than that observed by Niero et al. (2018) and Koczura et al. (2019a) in late-lactating Valdostana Red Pied cows, although their cows had been fed $2 \mathrm{~kg}$ of concentrate/d, unlike the cows in the present study. Montbéliarde did not produce less milk per day than Holstein cows, in contrast to what Pires et al. (2015) observed in an extensive grazing system. Walking exercise and truck transport stress might have prevented the Holstein cows in the present study from expressing their full milk yield potential. We observed a decreasing gradient in protein and casein content from Valdostana Red Pied to Montbéliarde and Holstein cows. Usually, milk from cows in late lactation has higher fat and pro- 
tein content, but in the present study, the unexpectedly low protein content of milk from Holstein cows could also point toward a negative energy balance (Coulon and Rémond, 1991). Milk pH was lowest in Valdostana Red Pied cows and highest in Holstein cows. This difference was consistent with the findings of Macheboeuf et al. (1993) and the longer rennet coagulation time observed for milk from Holstein cows compared with milk from Montbéliarde (+6.2 min) and Valdostana Red Pied (+5.8 min) cows. Curd firmness $\left(\mathrm{a}_{30}\right)$ for milk from Holstein was half that for milk from both other breeds, which can be explained by its longer rennet coagulation time and lower casein content. Of the Holstein samples, $42 \%$ did not coagulate, compared with only $6 \%$ of Valdostana Red Pied samples and $13 \%$ of Montbéliarde samples (Table 3). Holstein milk is well known for its poor ability to coagulate (De Marchi et al., 2013), which can be linked to its low frequency of the K-casein B allele (Delacroix-Buchet et al., 1993; Macheboeuf et al., 1993). Indeed, Chen et al. (2017) reported a B-allele frequency of $17 \%$ for milk from Holsteins in the United Kingdom, and Vallas et al. (2012) reported that $4 \%$ of Estonian Friesian Holstein cows had the BB genotype. This low frequency compared with Montbéliarde (55\%; OS Montbéliarde, 2014) and Valdostana Red Pied (76\%; Assoziazione Nazionale Allevatori Bovini di Razza Valdostana, 2010) might be the main explanation for the poorer coagulation ability of their milk, regardless of moving treatment.
Considering these differences across breed types, we expected that cows with higher genetic merit for milk production would suffer more from walking and truck transport, as demonstrated by Coulon and Pradel (1997) when comparing Montbéliarde with loweryielding Tarentaise cows. Magrin et al. (2016) found that high-yielding cows substantially decreased their milk yield after a long walk under mountainous conditions, and by a higher proportion than low-yielding cows ( $-49 \%$ vs. $-32 \%$, respectively). In the present study, the limited severity of the moving exercise might have prevented such differences. Although the Valdostana Red Pied cows (a breed type with low genetic merit) were likely more used to transhumance involving walking and truck transport than the Montbéliarde and Holstein cows, the experience of the latter 2 breeds in walking between different pastures and back and forth to the barn for each milking might have helped them cope with the different treatments. At an individual level, cows make tradeoffs and prioritize lactation, reproduction, or boundary conditions to survive (Blanc et al., 2006). Cows mobilize body fat reserves to prioritize lactation over reproduction and vital functions, or conversely, reproduction at the expense of milk yield (Ollion et al., 2016). Differences are likely more pronounced in early lactation, when the need for tradeoff is even higher. According to Friggens et al. (2017), repeated measurements over time have a high potential to quantify an animal's ability to cope with challenges.

Table 4. Least squares means of milk yield, milk properties, and cow blood metabolites for breed effect

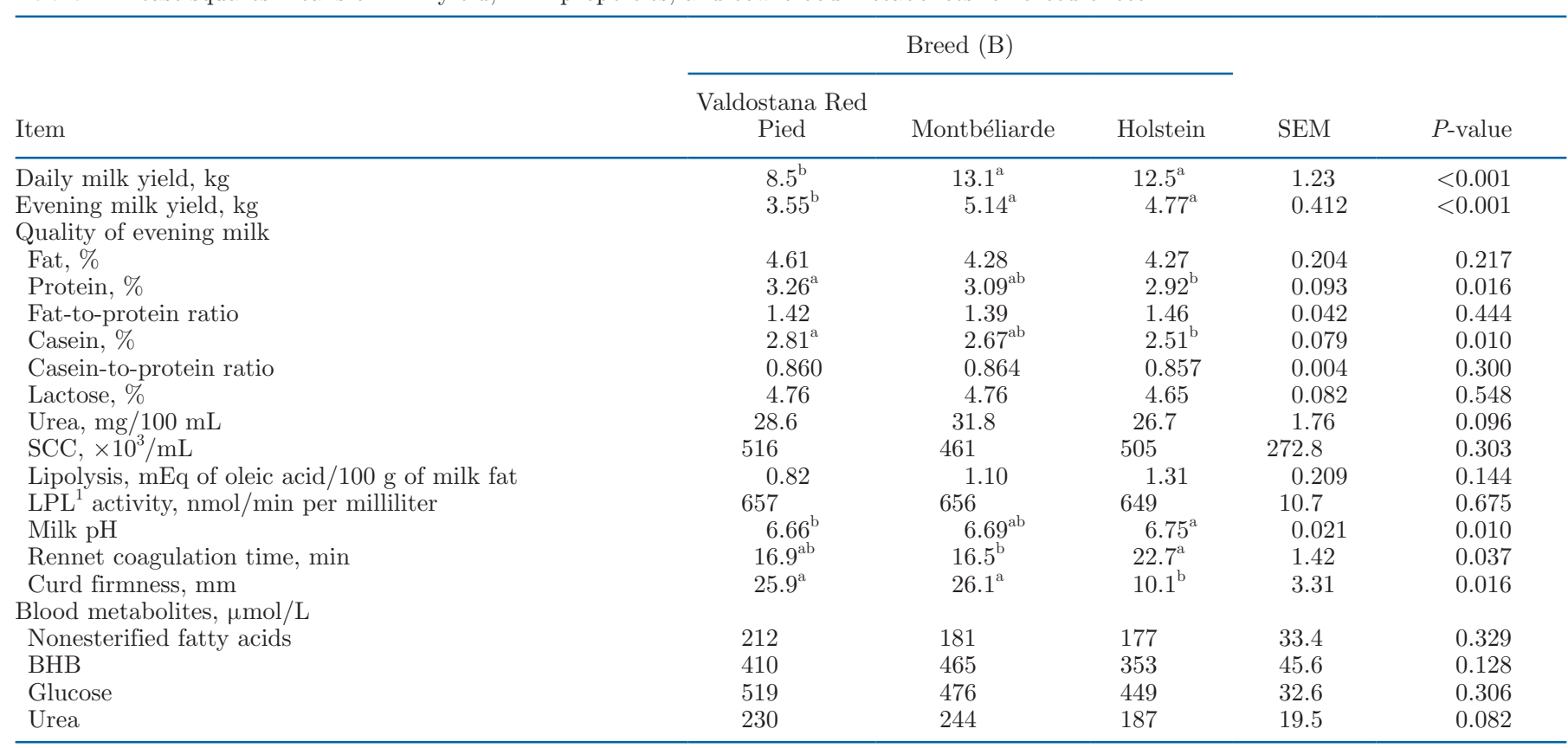

${ }^{\mathrm{a}, \mathrm{b}}$ Values within a row with different superscripts differed at $P<0.05$.

${ }^{1}$ Lipoprotein lipase. 
Therefore, after energy-demanding treatments such as those investigated in the present study, further investigation is necessary, involving repetition of treatments over years and considering the main vital functions in the long term, to better characterize the hypothesized inherited adaptation of breeds of low genetic merit.

\section{CONCLUSIONS}

When we simulated conditions of transhumance applied in farm practice, a 6-km walk decreased milk yield and increased plasma NEFA and milk SCC. We compared this to $1 \mathrm{~h}$ of truck transport, which did not decrease milk yield, but did increase plasma NEFA and changed milk quality by increasing both milk fat content and SCC. In contrast to our expectations, response to stressful movement treatments was not stronger in cows with a higher genetic merit for milk yield than in cows considered robust. This may be because all cows were in late lactation, but this was the only stage in which mountainous grazing without supplementary feeding was realistic. Our study suggests that in mountainous dairy systems, transporting cows by truck could help to avoid strong decreases in milk yield the day after transhumance, although milk quality would be still be impaired. It would be interesting to investigate broader criteria over the long term to deepen comparisons of the 3 breeds, and to include higher altitudes and steep slopes in the walking exercise. Moreover, further studies should include cheese manufacturing to assess the consequences of walking and truck transport of cows on final products.

\section{ACKNOWLEDGMENTS}

The authors acknowledge the support by the French government IDEX-ISITE initiative 16-IDEX-0001 (CAP 20-25). We are grateful to the staff at the experimental unit of Marcenat; S. Zurmühle (ETH Zurich, Switzerland); M. Coppa, A. Ferlay, and J. Pires (INRAE, Paris, France); and G. Peratoner (Laimburg, Italy), for their help in sample collection, laboratory analysis, data interpretation, and statistical advice. We thank F. Trouilloud (Linguistic Consulting, France) for proofreading our manuscript. The authors have not stated any conflicts of interest.

\section{REFERENCES}

Assoziazione Nazionale Allevatori Bovini di Razza Valdostana. 2010. Accessed June 14, 2019. http://www.anaborava.it/rzz_duplice .html.

Blanc, F., F. Bocquier, J. Agabriel, P. D'Hour, and Y. Chilliard. 2006. Adaptive abilities of the females and sustainability of ruminant livestock systems. A review. Anim. Res. 55:489-510. https://doi .org/10.1051/animres:2006040.

Cassandro, M., A. Comin, M. Ojala, R. Dal Zotto, M. De Marchi, L. Gallo, P. Carnier, and G. Bittante. 2008. Genetic parameters for milk coagulation properties and their relationships with milk yield and quality traits in Italian Holstein cows. J. Dairy Sci. 91:371376. https://doi.org/10.3168/jds.2007-0308.

Chazal, M. P., and Y. Chilliard. 1986. Effect of stage of lactation, stage of pregnancy, milk yield and herd management on seasonal variation in spontaneous lipolysis in bovine milk. J. Dairy Res. 53:529-538. https://doi.org/10.1017/S0022029900033057.

Chen, B., A. S. Grandison, and M. J. Lewis. 2017. Best use for milkA review. I. Effect of breed variations on the physicochemical properties of bovine milk. Int. J. Dairy Technol. 70:3-15. https:// doi.org/10.1111/1471-0307.12352.

Coulon, J. B., and P. Pradel. 1997. Effect of walking on roughage intake and milk yield and composition of Montbéliarde and Tarentaise dairy cows. Ann. Zootech. 46:139-146. https://doi.org/10 .1051/animres:19970204.

Coulon, J. B., and B. Rémond. 1991. Variations in milk output and milk protein content in response to the level of energy supply to the dairy cow: A review. Livest. Prod. Sci. 29:31-47. https://doi .org/10.1016/0301-6226(91)90118-A.

Coulon, L. B., A. Delacroix-Buchet, B. Martin, and A. Pirisi. 2004. Relationships between ruminant management and sensory characteristics of cheeses: A review. Lait 84:221-241. https://doi.org/10 .1051/lait:2004008.

D'Hour, P., A. Hauwuy, J. Coulon, and J. Garel. 1994. Walking and dairy-cattle performance. Ann. Zootech. 43:369-378. https://doi .org/10.1051/animres:19940406.

De Marchi, M., V. Toffanin, M. Cassandro, and M. Penasa. 2013. Prediction of coagulating and noncoagulating milk samples using mid-infrared spectroscopy. J. Dairy Sci. 96:4707-4715. https://doi .org/10.3168/jds.2012-6506.

Delacroix-Buchet, A., D. Lefier, and V. Nuyts-Petit. 1993. Polymorphisme de la caséine $\mathrm{K}$ de trois races bovines françaises et aptitude à la coagulation. Lait 73:61-72. https://doi.org/10.1051/lait: 199313.

Ferlay, A., B. Martin, P. Pradel, J. B. Coulon, and Y. Chilliard. 2006. Influence of grass-based diets on milk fatty acid composition and milk lipolytic system in Tarentaise and Montbeliarde cow breeds. J. Dairy Sci. 89:4026-4041. https://doi.org/10.3168/jds.S0022 -0302(06)72446-8.

Friggens, N. C., F. Blanc, D. P. Berry, and L. Puillet. 2017. Review: Deciphering animal robustness. A synthesis to facilitate its use in livestock breeding and management. Animal 11:2237-2251. https: //doi.org/10.1017/S175173111700088X.

Hauswirth, C. B., M. R. L. Scheeder, and J. H. Beer. 2004. High omega-3 fatty acid content in alpine cheese: The basis for an alpine paradox. Circulation 109:103-107. https://doi.org/10.1161/ 01.CIR.0000105989.74749.DD.

Hong, H., E. Lee, I. H. Lee, and S.-R. Lee. 2019. Effects of transport stress on physiological responses and milk production in lactating dairy cows. Asian-Australas. J. Anim. Sci. 32:442-451. https://doi .org/10.5713/ajas.18.0108.

Ikonen, T., K. Ahlfors, R. Kempe, M. Ojala, and O. Ruottinen. 1999. Genetic parameters for the milk coagulation properties and prevalence of noncoagulating milk in Finnish dairy cows. J. Dairy Sci. 82:205-214. https://doi.org/10.3168/jds.S0022-0302(99)75225-2.

Ishizaki, H., and Y. Kariya. 2010. Road transportation stress promptly increases bovine peripheral blood absolute NK cell counts and cortisol levels. J. Vet. Med. Sci. 72:747-753. https://doi.org/10.1292/ jvms.09-0441.

ISO 9622. 2013. Milk and liquid milk products - Guidelines for the application of mid-infrared spectrometry. International Organization for Standardization, Geneva, Switzerland.

ISO 13366-2. 2006. Milk-Enumeration of somatic cells-Part 2: Guidance on the operation of fluoro-opto-electronic counters. International Organization for Standardization, Geneva, Switzerland.

Koczura, M., B. Martin, G. Turille, M. DeMarchi, M. Kreuzer, and J. Berard. 2019b. Milk composition, but not cheese properties, are 
impaired the day after transhumance to alpine pastures. Int. Dairy J. 99:104540. https://doi.org/10.1016/j.idairyj.2019.104540.

Koczura, M., S. Pervier, E. Manzocchi, G. Turille, R. M. Bruckmaier, M. Kreuzer, and J. Berard. 2019a. Previous alpine grazing experience of cows has little medium-term effect on feeding behaviour, milk yield and composition in a traditional alpine system. Ital. J. Anim. Sci. 18:410-422. https://doi.org/10.1080/1828051X.2018 .1532326 .

Kreuzer, M., W. Langhans, F. Sutter, R. E. Christen, H. Leuenberger, and P. L. Kunz. 1998. Metabolic response of early-lactating cows exposed to transport and high altitude grazing conditions. Anim. Sci. 67:237-248. https://doi.org/10.1017/S1357729800009991.

Leiber, F., D. Nigg, C. Kunz, M. R. L. Scheeder, H.-R. Wettstein, and M. Kreuzer. 2005. Protein composition, plasmin activity and cheesemaking properties of cows' milk produced at two altitudes from hay of lowland and high-alpine origins. J. Dairy Res. 72:65-74. https://doi.org/10.1017/S0022029904000615.

Macheboeuf, D., J.-B. Coulon, and P. D'Hour. 1993. Effect of breed, protein genetic variants and feeding on cows' milk coagulation properties. J. Dairy Res. 60:43-54. https://doi.org/10.1017/ S0022029900027333.

Magrin, L., M. Brscic, I. Lora, B. Contiero, and G. Cozzi. 2016. Physiological and productive response of lactating dairy cows to the alpine transhumance at the end of the summer grazing. Ital. J. Anim. Sci. 15:151-156. https://doi.org/10.1080/1828051X.2015 .1132541

Minka, N. S., and J. O. Ayo. 2010. Physiological responses of food animals to road transportation stress. Afr. J. Biotechnol. 9:6601-6613.

Niero, G., M. Koczura, M. De Marchi, S. Curro, M. Kreuzer, G. Turille, and J. Berard. 2018. Are cheese-making properties of dual purpose cattle impaired by highland grazing? A case study using Aosta Red Pied cows. Ital. J. Anim. Sci. 17:827-834. https://doi .org/10.1080/1828051X.2018.1443289.

Ollion, E., S. Ingrand, L. Delaby, J. M. Trommenschlager, S. ColetteLeurent, and F. Blanc. 2016. Assessing the diversity of trade-offs between life functions in early lactation dairy cows. Livest. Sci. 183:98-107. https://doi.org/10.1016/j.livsci.2015.11.016.
OS (Organisme de Sélection) Montbéliarde. 2014. Un lait idéal pour le fromager. Accessed Feb. 4, 2020. https://www.montbeliarde.org/ un-lait-ideal-pour-le-fromager.html.

Pires, J. A., Y. Chilliard, C. Delavaud, J. Rouel, D. Pomiès, and F. Blanc. 2015. Physiological adaptations and ovarian cyclicity of Holstein and Montbéliarde cows under two low-input production systems. Animal 9:1986-1995. https://doi.org/10.1017/ S1751731115001317.

Vallas, M., T. Kaart, S. Värv, K. Pärna, I. Jõudu, H. Viinalass, and E. Pärna. 2012. Composite $\beta$ - $\kappa$-casein genotypes and their effect on composition and coagulation of milk from Estonian Holstein cows. J. Dairy Sci. 95:6760-6769. https://doi.org/10.3168/jds.2012 -5495 .

Vanbergue, E., J. L. Peyraud, A. Ferlay, G. Miranda, P. Martin, and C. Hurtaud. 2018. Effects of feeding level, type of forage and milking time on milk lipolytic system in dairy cows. Livest. Sci. 217:116-126. https://doi.org/10.1016/j.livsci.2018.09.019.

Visentin, G., A. McDermott, S. McParland, D. P. Berry, O. A. Kenny, A. Brodkorb, M. A. Fenelon, and M. De Marchi. 2015. Prediction of bovine milk technological traits from mid-infrared spectroscopy analysis in dairy cows. J. Dairy Sci. 98:6620-6629. https://doi.org/ 10.3168/jds.2015-9323.

Zendri, F., M. Ramanzin, G. Bittante, and E. Sturaro. 2016. Transhumance of dairy cows to highland summer pastures interacts with breed to influence body condition, milk yield and quality. Ital. J. Anim. Sci. 15:481-491. https://doi.org/10.1080/1828051X.2016 .1217176 .

\section{ORCIDS}

M. De Marchi $\odot$ https://orcid.org/0000-0001-7814-2525

M. Kreuzer @ https://orcid.org/0000-0002-9978-1171

J. Berard $\odot$ https://orcid.org/0000-0002-7222-632X

B. Martin ๑ https://orcid.org/0000-0003-2501-8306 